The Princeton

Companion to

Classical

Japanese Literature 



\section{The Princeton}

Companion to

Classical

Japanese Literature

BY Earl Miner, Hiroko Odagiri,

A ND Robert E. Morrell

Princeton University Press, Princeton, N. J. 
Copyright $(\mathcal{C} 1985$ by Princeton University Press

Published by Princeton University Press, 41 William Street,

Princeton, New Jersey 08540

In the United Kingdom: Princeton University Press, Chichester, West Sussex

All Rights Reserved

\section{Library of Congress Cataloging in Publication Data}

Miner, Earl Roy.

The Princeton companion to classical Japanese literature.

Bibliography: $\mathrm{p}$.

Includes index.

1. Japanese literature-To 1868-Handbooks, manuals, etc. I. Odagiri, Hiroko.

II. Morrell, Robert E. III. Title.

PL726.1.M495 $1984 \quad 895.6^{\prime} 09 \quad 83-24475$

ISBN 0-691-06599-3 (alk. paper)

ISBN 0-691-00825-6 (pbk.)

Second printing, 1988

$\begin{array}{llllll}9 & 8 & 7 & 6 & 5 & 4\end{array}$

Publication of this book has been aided by grants

from the Whitney Darrow Fund of Princeton University Press

and the Japan Foundation

Princeton University Press books are printed on acid-free paper and meet the guidelines for permanence and durability of the Committee on Production Guidelines for Book Longevity of the Council on Library Resources

Printed in the United States of America by Princeton Academic Press 
For

our fellow students of Japanese literature 
